\title{
Production and export performance of spices from India
}

\begin{abstract}
Non-Tariff Barriers to Trade is becoming a big constraint to many nations in respect of export of farm produce because of the restrictions towards maintaining food safety and standards for the health awareness. Due to this restriction, many of the export has become decreased in terms of its quantity and value and few of the commodities have performed well in respect of production and export. Red Chilli is one of the spice commodity performed well amidst different Non-Tariff Measures and hence this paper has presented the production and export performance that took place in a three decade of time revealed that the production and export of spices found to be on the increasing phase.
\end{abstract}

Keywords: production of spices, export of spices, red chilli, compound growth rate, performance of spices
Volume 2 Issue 6 - 2018

P Muthupandi,' C Sekhar, ${ }^{2}$ KR Karunakaran²

'Research Scholar, Department of Agricultural Economics, India

${ }^{2}$ Professor, Department of Agricultural Economics, India

Correspondence: Sekhar C, Department of Agricultural

Economics, Tamil Nadu Agricultural University,

Coimbatore-641003, India, Email saekarck@gmail.com

Received: July 30, 2018 | Published: December 19, 2018

\section{Introduction}

Non-Tariff Barriers to Trade is sometimes called as "Non-Tariff Measures" which are trade barriers that restrict imports or exports of goods and services through the mechanisms other than the simple imposition of Tariffs. Conceptually a Non-Tariff Barrier is any obstacle to international trade that is not an import or export duty. They may take the form of Import quotas, subsidies, customs delays, technical barriers or other systems preventing or impeding the trade. According to World Trade Organization, Non-Tariff Barriers to Trade include import licensing, rules for valuation of goods at customs, preshipment inspections, rules of origin and trade prepared investment measures.

India is actively following the Free Trade Agreements especially in Agricultural and Processed Food Products as enunciated by World Trade Organization. While Free Trade Agreements impose certainly a reduced tariffs, the gains from such free trade becomes limited in the presence of Non-Tariff Barriers which will be a different one from country to country based on their preferences and nature of transactions made.

Any Trader who is focusing his services on exporting the farm produce particularly the Red Chilli to any other country who actually demands heavily on the produce from India faces some kind of constraints or some barriers in effecting the trade. The barriers which prevents or hinders the trade is otherwise designated as Tariff Barriers and Non-Tariff Barriers. This was clearly explained by the World Trade Organization and gave some special prescriptions on it and hence every trader who is actually willing to place the Indian product in the soils of any other nation needs to follow some guidelines, need to have some quality parameters or standards; need to follow some hygienic practice and deliver the produce free from infected status and to follow the size prescriptions for easy handling and usage. In this situation, the discussion on Non-Tariff Barriers and its impact on the production and export of Red Chilli becomes much important to the stakeholders and hence this study.

\section{Design of the study}

Amidst the Different import regulations imposed by different nations and the certification requirements towards hazard analysis as Non-Tariff Barriers, how India has performed in respect of both the production and export of Spices and Red Chilli need to be assessed. For that the time series data on production of Spices and Export of Spices were gathered from the Web Site of Spices Board and the same were subjected to growth rate analysis. Compound growth rate (CGR) was used for the purpose utilizing the following formula. The form is

$$
\mathrm{Y}=\mathrm{a} \mathrm{b}^{\mathrm{t}} \mathrm{e}_{\mathrm{t}}
$$

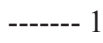

Where,

$$
\begin{aligned}
& \mathrm{Y}=\text { Dependent variable for which growth rate is estimated } \\
& \mathrm{a}=\text { Intercept } \\
& \mathrm{b}=\text { Regression co-efficient } \\
& \mathrm{t}=\text { Time variable } \\
& \mathrm{e}=\text { Error term }
\end{aligned}
$$

The compound growth rate was obtained using the logarithmic form of the equation (1) as detailed below.

$$
\text { In } \mathrm{Y}=\ln \mathrm{a}+\ln b
$$

Then, compound growth rate (r) in per cent was computed by using the relationship

$$
r=[(\text { Antilog of } b)-1] \times 100
$$

The compound growth rates were tested for their significance by the statistics given by

$$
\mathrm{t}=\mathrm{r} / \mathrm{SE}(\mathrm{r})
$$

where, 
$\mathrm{SE}(\mathrm{r})=[100 \mathrm{xb} \times \mathrm{SE}(\operatorname{lnb})] / \ln \mathrm{e}$

The study conducted from January 2018 to April 2018

\section{Results and discussion}

Because of the various developmental initiatives including establishment of Spices Parks in select state locations, the area and production of different spices found to be increased. These details are analyzed and the results are presented in Table 1.

Table 1 revealed the details of Area and Production of Major Spices in India. When comparing the area during the year 2014-15 and 2015-16, the area under total spices found to be increased only to the tune of 5.26 per cent. The production figures in respect of total spices in India found to show only 12.46 per cent increase during the year 2015-16 over the year 2014-15. Whereas, the area under Chilli during the year 2015-16 is found to show a decreasing trend over the year 2014-15.

The decrease in area was taken away by the Coriander, Fennel and Fenugreek whose area were found to be increased during the year

Table I Area and production of major spices in India
2015-16 which are respectively accounted for 13 per cent; 96 per cent and 85 per cent. The production of Chilli also reduced during the year 2015-16. It might be mainly due to non-adoption of appropriate technology by the farmers. Though the Spices Park were also established in Tamil Nadu, it has not paid much dividend in respect of Chilli. However, the production performance of Red Chilli was assessed over a period of time by drawing time series data from 198889 to 2016-17 by using Compound Growth Rate in respect of area, production and productivity of Chilli. These details are presented in Table 2.

Table 2 revealed that the area under Red Chilli was found to decrease to the tune of 0.48 per cent per annum. During the year 200506 , India has witnessed a drastic reduction in area under Chillies to the tune of 2.35 lakhs ha. Later on, the area under Chilli found to be increased. The increase in area between 2005-06 and 2016-17 might be due to the intervention of National Horticulture Mission focusing Area Expansion component for spice and vegetable crops. In respect of production of Chilli, it is found to be growing constantly and reached a peak after 2009-10. The Production was found to grow at the rate of 3.13 per cent per annum.

\begin{tabular}{llllll}
\hline $\begin{array}{l}\text { SI. } \\
\text { No }\end{array}$ & $\begin{array}{l}\text { Name of the } \\
\text { spices }\end{array}$ & $\begin{array}{l}\text { Area (Ha) under } \\
\text { apices (2014-15) }\end{array}$ & $\begin{array}{l}\text { Production of spices } \\
(\mathbf{2 0 1 4 - 1 5 )} \text { in tonnes }\end{array}$ & $\begin{array}{l}\text { Area (Ha) under } \\
\text { spices } \\
(\mathbf{2 0 1 5} \text {-16) }\end{array}$ & $\begin{array}{l}\text { Production (20 I5-16) } \\
\text { in tonnes }\end{array}$ \\
\hline 01 & Pepper & 123900 & 70000 & $131790(6.37)$ & 48500 \\
02 & Chilli & 766400 & 1631320 & $742950(-) 3.06$ & $1497440(-) 8.21$ \\
03 & Ginger & 140940 & 755950 & $156910(11.33)$ & 1025110 \\
04 & Turmeric & 188020 & 844470 & $183480(-) 2.41$ & 967060 \\
05 & Garlic & 261950 & 1424770 & $295600(12.85)$ & 1603500 \\
06 & Coriander & 552440 & 462270 & $624780(13.09)$ & 572990 \\
07 & Cumin & 889760 & 485500 & $808230(-) 9.16$ & 503260 \\
08 & Fennel & 38660 & 59740 & $76000(96.59)$ & 129350 \\
09 & Fenugreek & 123340 & 130810 & $227960(84.82)$ & 248350 \\
\hline
\end{tabular}

\section{Source Spices Board, 2016-17.}

In respect of productivity of Chilli, the Compound Annual Growth Rate was arrived at 3.614 indicating that the productivity of Chilli is growing at the rate of 3.61 per cent per annum. However, remarkable achievement in productivity is visible only during the period of 2016-17. It might be due to the practice of adoption of precision technologies at field. The steady growth in productivity is visible from 2005-06 because of the intervention of National Horticulture Mission. The growth trends in respect of Area (Figure 1).

The Figure implied that the year 2002-03 found to be the year of lowest production and productivity of Chilli. From the year 2003-04 onwards, the production and productivity found to increase steadily with a fall during 2005-06 and later on a steady growth is visible. The reason for the lowest production and productivity might be due to the poor rainfall during those periods. In this situation, the role of extension functionaries need to be made intensive on developing cropping schedule and the same may be prescribed to the farmers to enhance the production and productivity of Chilli particularly in the Chilli belt by motivating the farmers to practice proven technologies in an organic way considering the traceability aspects for export of Chilli. Under this production scenario, one should assess whether all the production has been consumed locally or exported partially to different demanding destinations are the need of the hour and hence these details are analyzed and the results are presented in Table 3. 
Table 2 Compound growth rate of red chilli

\begin{tabular}{lllll}
\hline SI. No & Year & Area in Ha & Production in tonnes & Productivity $(\mathbf{K g} / \mathrm{Ha})$ \\
\hline 01 & $1988-89$ & 805000 & 680400 & 845 \\
02 & $1995-96$ & 883700 & 809700 & 916 \\
03 & $1999-2000$ & 977530 & 1056000 & 1080 \\
04 & $2005-2006$ & 742200 & 1023128 & 1378 \\
05 & $2010-11$ & 792000 & 1223000 & 1544 \\
06 & $2016-17$ & 830770 & 1872010 & 2253 \\
\multicolumn{2}{l}{ CAGR in Per Cent } & $(-) 0.483$ & 3.131 & 3.614 \\
\hline
\end{tabular}

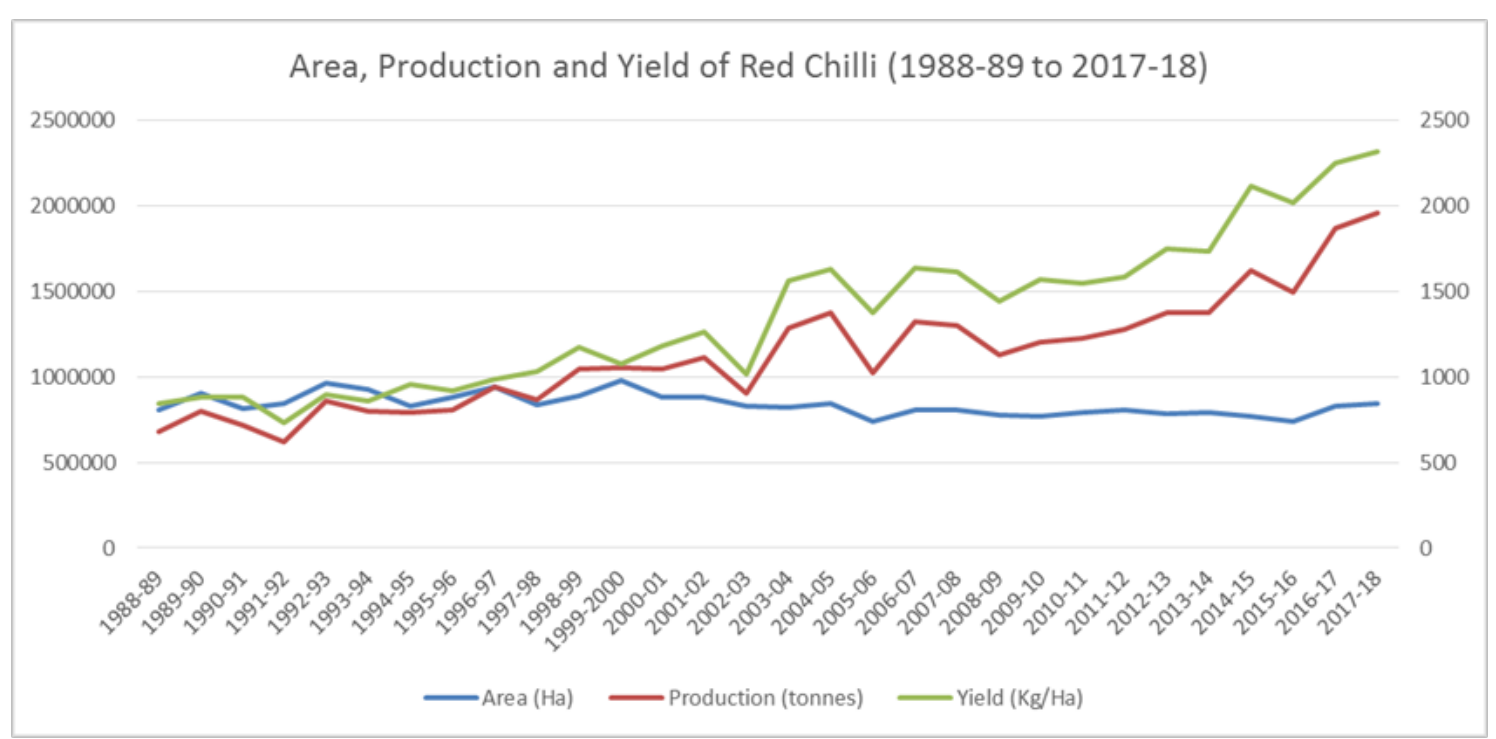

Figure I Production and productivity of chilli is presented.

Table 3 Export of spices from india (quantity in tonnes)

\begin{tabular}{|c|c|c|c|c|}
\hline 01 & Pepper & 28100 & 17600 & $(-) 37.37$ \\
\hline 02 & Cardamom (S) & 5500 & 3850 & (-) 30.00 \\
\hline 03 & Cardamom (L) & 600 & 780 & 30.00 \\
\hline 05 & Ginger & 24800 & 24950 & 00.60 \\
\hline 06 & Turmeric & 88500 & 116500 & 31.64 \\
\hline 07 & Coriander & 40100 & 30300 & $(-) 24.43$ \\
\hline 10 & Fennel & 15320 & 35150 & 129.44 \\
\hline 11 & Fenugreek & 33330 & 34680 & 04.05 \\
\hline 12 & Other Seeds* & 23880 & 18100 & (-) 24.00 \\
\hline 13 & Garlic & 23085 & 32200 & 39.48 \\
\hline
\end{tabular}




\begin{tabular}{|c|c|c|c|c|}
\hline SI. No & Details of spices & $\begin{array}{l}\text { Quantity exported } \\
\text { during 2015-16 }\end{array}$ & $\begin{array}{l}\text { Quantity exported } \\
\text { during 2016-17 }\end{array}$ & $\begin{array}{l}\text { Percentage change during } \\
2016-17\end{array}$ \\
\hline 14 & Nutmeg and Mace & 4050 & 5070 & 25.19 \\
\hline 15 & Other Spices** & 43955 & 40210 & $(-) 08.52$ \\
\hline 16 & $\begin{array}{l}\text { Curry Powders/ } \\
\text { Paste }\end{array}$ & 26550 & 28500 & 07.55 \\
\hline 17 & Mint Products@ & 23250 & 22300 & (-) 04.09 \\
\hline 18 & $\begin{array}{l}\text { Spice Oils and } \\
\text { Oleoresins }\end{array}$ & 11635 & 12100 & 04.00 \\
\hline \multicolumn{2}{|c|}{ Total Export of Spices } & 843255 & 947790 & 12.40 \\
\hline \multicolumn{2}{|c|}{ Total Production of Spices } & 6595560 & & \\
\hline \multicolumn{4}{|c|}{ Percentage of Export on Total Production } & 12.79 \\
\hline
\end{tabular}

*includes Mustard, Aniseeds, Ajwan seeds, Dill Seeds, Poppy Seeds etc.

**Includes Tamarind, Asafoetida, Cassia, Saffron etc.

@Includes Mint Oils, Menthol and Menthol Crystal.

Table 3 revealed the details of Export of various spices from India. Among the variety of spices, the largest quantity exported from India was found to be Chilli which is arrived at 4 lakh tonnes during the year 2016-17. When comparing the export figures of 2016-17 and 2015-16, the Chilli export was increased to the tune of 15 per cent in one year amidst the decrease in area under Chilli. It might be due to enhancement in the productivity of Chilli during these periods in certain pockets of India especially the southern India. Similar to Chilli, enhanced export quantity is visible in certain spices. They are Large Cardamom, Turmeric, Cumin, Celery, Fennel, Fenugreek, Curry Powders and Spice Oils like Oleoresin. Among the increase in export quantity, the largest export quantity took place in respect of Fennel during the year 2016-17.

The decrease in export quantity during the year 2016-17 is visible in respect of Pepper, Short Cardamom, Coriander, Spice Seeds and Mint products. Among these, export of pepper was found to face a 37 per cent decrease during the year 2016-17 over the year 201516. The Spices Board and the other organizations in connection with export of spices has to find the reasons for the shortfall in export of Pepper amidst increased production of Pepper. Following the coding system and after meeting the conditions of importing countries by the exporters cum traders, the export of Red Chilli from India has grown to certain extent in some of the countries in a decade of time which was arrived at and the results are presented in Table 4.

Table 4 revealed the details of export of Red Chilli to different nations during the year 2006-07 and 2016-17. Presentation of data on Red Chilli export in a decade of time is to highlight the decadal change in the export among different nations. Few of the countries are so friendly to India in receiving the increased consignments of Red Chilli regularly. Whereas, very few nations have started reducing their demand note with regard to import of Red Chilli from India. It might be due to the area expansion took place under Red Chilli in their own country and productivity would have been enhanced to meet their demand or the respective country would have imported the Red Chilli from some other nations because of Price and quality advantage of Red Chilli.
India is exporting Red Chilli to more than 20 countries across the world. Among these, Vietnam, Thailand, Sri Lanka, Bangladesh and Indonesia are the five top most nations importing the Indian Red Chilli considerably. Their import quantity during the year 201617 was found to be $70012,60008,51393,39685$ and 33394 tonnes respectively. When one could compare the export data of 2016-17 with that of 2006-07, Vietnam is the only country has demanded the highest quantity of Red Chilli during the year 2016-17. Earlier the export data is not figured in respect of Vietnam revealed that the country is the new entry to the import of Red Chilli from India.

Thailand is the country which has imported very less quantity during the beginning of the decade (2006-07) and when we compare the data during the year 2016-17, the increase in the import is found to be 9472 per cent over the year 2006-07. Whereas, the Sri Lanka has imported the Indian Chilli to the tune of around 51393 tonnes which is accounted for 135 per cent increase over the year 2006-07. The countries which are showing much interest in importing the Indian Red Chilli to their destination are Thailand, Mexico, Indonesia, United Arab Emirate, Saudi Arabia and United Kingdom. The percentage increase in the export of Red Chilli during the year 2016-17 is found to be greater than 200 per cent over the year 2006-07. Though Nepal is a small country, its import statistics in respect of Red Chilli is also appreciable. The percentage increase in the import of Red Chilli to their destination is arrived at 170 per cent during the year 2016-17 over the year 2006-07. The overall increase in the Red Chilli export to different nations is accounted for 169 per cent.

Russia and Malaysia are the only two nations had shown disinterest in importing Red Chilli from India. The Trade Promotion Organization placed in these countries should find the reasons behind non acceptance of Red Chilli or denial of Red Chilli import to their destinations and an appropriate strategy should be taken by the Agricultural and Processed Food Products Export Development Authority (APEDA) on time to rejuvenate the trade ties with those destinations. The Magnitude of Indian Spice and Chilli exports over years is presented in Figure 2. 
Figure 1, Figure 2 implied that the export quantity of spices and Red Chilli found to take a new upward trend from 2010-11 to 2016-17

Table 4 Details of export of red chilli from india to different nations

\begin{tabular}{|c|c|c|c|c|}
\hline SI. No & Name of the country & $\begin{array}{l}\text { Quantity exported in tonnes } \\
\text { during 2006-07 }\end{array}$ & $\begin{array}{l}\text { Quantity exported in tonnes } \\
\text { during 2016-17 }\end{array}$ & $\begin{array}{l}\text { Percentage } \\
\text { change }\end{array}$ \\
\hline 01 & Malaysia & 43625.400 & 28791.870 & (-) 34.00 \\
\hline 02 & Sri Lanka & 21822.400 & 51392.560 & 135.50 \\
\hline 03 & United States (USA) & 13058.200 & 20792.36 & 59.23 \\
\hline 04 & United Arab Emirate & 12622.600 & 38318.37 & 203.57 \\
\hline 05 & Indonesia & 6488.500 & 33393.850 & 414.66 \\
\hline 06 & United Kingdom & 2279.400 & 6829.830 & 199.63 \\
\hline 07 & South Africa & 1738.400 & 2022.640 & 16.35 \\
\hline 08 & Saudi Arabia & 806.100 & 2426.700 & 201.08 \\
\hline 09 & Singapore & 1285.600 & 3277.360 & 154.93 \\
\hline 10 & Nepal & 3264.100 & 8812.200 & 169.97 \\
\hline II & Bangladesh & 28424.600 & 39685.520 & 39.62 \\
\hline 12 & Mexico & 1894.700 & 13105.64 & 591.70 \\
\hline 13 & Russia & 870.700 & NA & (-) 100.00 \\
\hline 14 & Australia & 697.800 & 1587.350 & 127.48 \\
\hline 15 & Vietnam & 0000.000 & 70012.510 & 00.00 \\
\hline 16 & Thailand & 626.900 & 60008.770 & 9472.30 \\
\hline \multirow[t]{2}{*}{17} & Others & 9512.800 & 19792.470 & 108.06 \\
\hline & Total & 149022.200 & 400250.000 & 168.58 \\
\hline
\end{tabular}

NA, not available; (Source: India Stat, 2016-17)

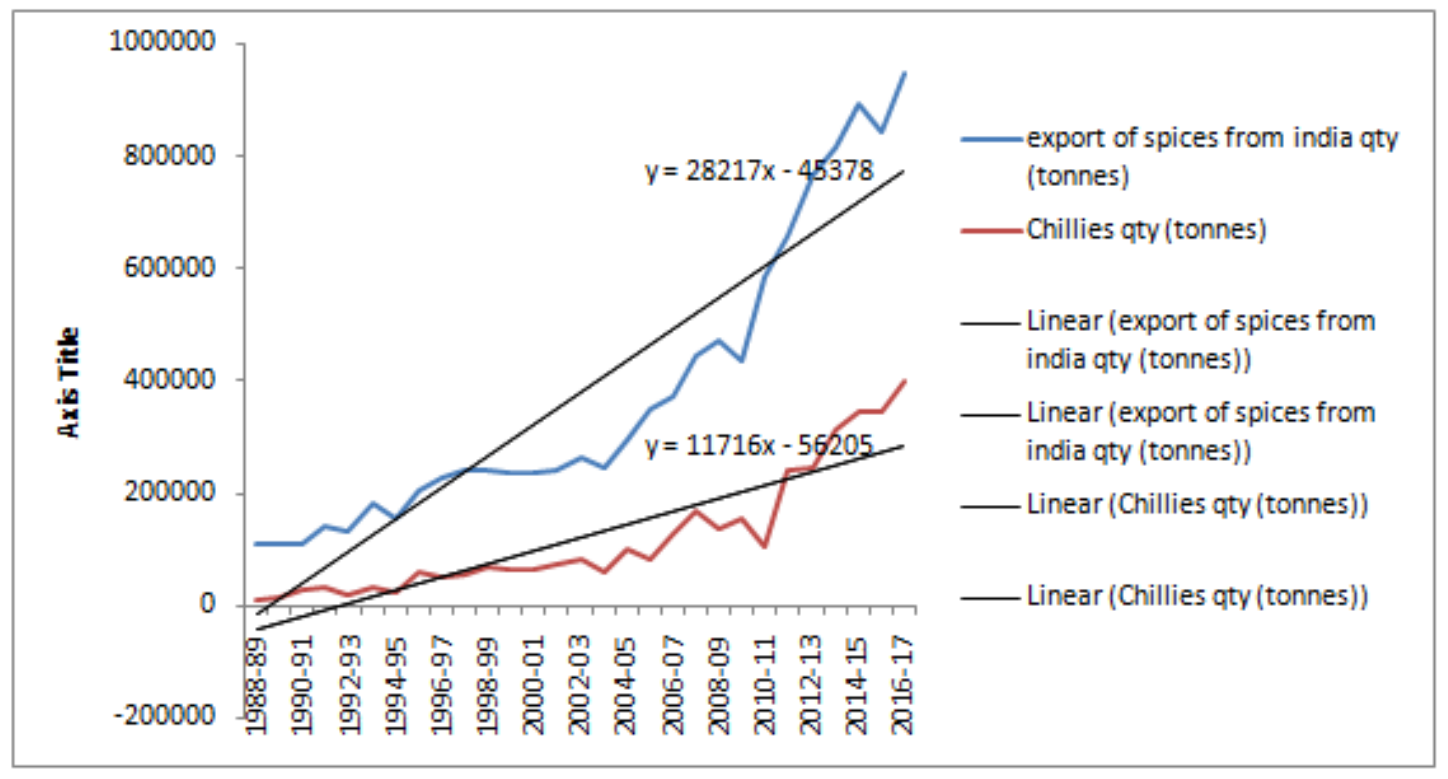

Figure 2 Trend in the export of spices and red Chilli.

Citation: Muthupandi P, Sekhar C, Karunakaran KR. Production and export performance of spices from India. Horticult Int J. 20I8;2(6):425-430. DOI: I0.15406/hij.20I8.02.00090 


\section{Conclusion and policy implications}

The production of spices in India was found to increase to the tune of 12.46 per cent during the year 2015-16 and the export of spices was found to increase to the tune of 12.79 per cent during the year 201617 showing that the production and export was in similar magnitude. Whereas, the export of Chilli alone to different destinations was found to increase to the tune of 169 per cent indicating that the demand is ever increasing to the Chilli and its produce abroad and hence the Indian exporters and the traders involved in export has to contact the farmer clusters in producing the exportable product of Chilli further by making contractual arrangements with the producers following the traceability considerations.

\section{Acknowledgments}

None.

\section{Conflicts of interest}

Author declares that there is no conflict of interest

\section{References}

1. Government of India. SOP for export of dried chilli. Ministry of agriculture and farmers welfare, directorate of plant Protection, quarantine and storage: New Delhi; 2016;7-9.

2. Spices board. Spices board rolls out subsidy scheme to boost production and export. Business Standard; 2015.

3. https://help.cbp.gov/app/answers/detail/a_id/216/ /anti-dumping-\%28ad\%29-and-countervailing-duties- $\% 28 \mathrm{cvd} \% 29$ 